\title{
ISOLASI SELULOSA DARI TONGKOL JAGUNG SEBAGAI BAHAN PENGISI PEMBUATAN TABLET KLORFENIRAMIN MALEAT CETAK LANGSUNG
}

\author{
Adil Makmur Tarigan, Rosnike Merly Panjaitan, Antetti Tampubolon \\ Jurusan Farmasi Poltekkes Medan
}

\begin{abstract}
Abstrak
Biomassa secara sempit didefenisikan sebagai bahan (material) yang berasal dari tumbuhan terestrial (darat). Biomassa tumbuhan sebagian besar berupa biomassa lignoselulosa yang tersusun dari selulosa, hemiselulosa, dan lignin. Selain itu pectin, protein, lemak dan abu yang terdapat dalam jumlah kecil. Salah satu biomassa lignoselulosa adalah limbah tongkol jagung. Tongkol jagung merupakan bahan berlignoselulosa dengan kadar serat 49,99\% berpotensi sebagai sumber bahan baku pembuatan selulosa. Derivat selulosa merupakan eksipien yang penting dalam farmasi. Salah satu turunan selulosa adalah selulosa mikrokristal yang diperdagangan dikenal dengan nama Avicel yang sering digunakan sebagai bahan pembantu pembuatan tablet. Penelitian ini bertujuan mengisolasi selulosa dari tongkol jagung dan menggunakannya sebagai bahan pembantu pembuatan tablet Klorfeniramin Maleat (tablet CTM) cetak langsung. Tablet Klorfeniramin Maleat (tablet CTM) yang dibuat dengan bahan pembantu selulosa dari tonggkol jagung dibandingkan dengan tablet CTM yang dibuat dari Avicel dan tablet CTM yang beredar dipasar. Data persyaratan evaluasi tablet menurut Farmakope Indonesia Edisi IV diuji dengan SPSS for Windos 16 dengan mencari nilai uji kesamaan rata-rata. Isolasi selulosa dari tongkol jagung dengan proses maserasi dengan etanol kemudian dihidrolisa menggunakan asam klorida. Selulosa diperoleh 49,39 \% dengan optimum asam klorida konsentrasi $7 \%$. Selulosa Tongkol Jagung dapat digunakan sebagai bahan pembantu pembuatan tablet Klorfeniramin Maleat (tablet CTM) cetak langsung. Tidak ada perbedaan yang bermakna $(\alpha=0,05)$ antara Selulosa tongkol jagung hasil ekstraksi dengan asam klorida $7 \%$ dengan Avicel sebagai bahan pembantu pembuatan tablet Klorfeniramin Maleat (tablet CTM) cara cetak langsung.
\end{abstract}

Kata kunci : Tongkol Jagung, Selulosa, Tablet CTM

\subsection{Latar belakang}

Perkembangan dalam bidang pertanian dan industri pertanian seringkali menimbulkan peningkatan limbah pertanian yang sebagian besar merupakan limbah berlignoselulosa. Pemanfaatan limbah merupakan salah satu alternative untuk menaikkan nilai ekonomi limbah tersebut. Secara kimia limbah berlignoselulosa kaya akan selulosa yang dapat diolah menjadi produk-produk yang bernilai ekonomi (Nishizawa, 2002). Selulosa merupakan bagian penyusun utama jaringan tanaman berkayu. Bahan tersebut utamanya terdapat pada tanaman kertas, namun demikian pada dasarnya selulosa terdapat pada setiap jenis tanaman, termasuk tanaman semusim, tanaman perdu dan tanaman rambat bahkan tumbuhan paling sedernaha sekalipun (Fengel dan Wegener, 2010). Tanaman jagung termasuk jenis tanaman pangan yang diketahui banyak mengandung serat kasar dimana tersusun atas senyawa kompleks lignin, hemiselulosa dan selulosa (lignoselulosa), dan masing-masing merupakan senyawa-senyawa yang potensil dapat dikonversi menjadi senyawa lain secara kimia dan biologi (Sjostrom, 2005).

Tongkol jagung merupakan limbah pertanian yang dihasilkan dari proses pemipilan jagung. Menurut Suprapto (2002) bobot tongkol jagung sekitar $\pm 30 \%$ dari bobot pipilan yang besarnya dipengaruhi oleh varietas jagungnya, sedangkan sisanya adalah kulit dan biji jagung. Jika konversi terhadap produksi jagung di Sumatera Utara pada tahun 2012 sekitar 1.347 juta ton pipilan atau sekitar 1.336 juta ton pipilan tahun 2013, penurunan produksi $0,8 \%$ (Badan Pusat Statistik, 2013). Seiring dengan tingginya produksi jagung, maka akan bertambah pula limbah yang dihasilkan dari industry pangan dan pakan berbahan baku jagung. Limbah yang dihasilkan diantaranya adalah tongkol jagung yang biasanya tidak dipergunakan lagi ataupun nilai ekonominya sangat rendah. Umumnya tongkol jagung dibiarkan berserakan sehingga membusuk untuk dijadika pupuk organik, ataupun didaerah pedesaan tongkol jagung ini dapat dimanfaatkan sebagai obat diare (Suprapto dan Rasyid, 2002)

Tongkol jagung merupakan bahan berlignoselusa dengan kadar serat 44,99\% jauh lebih tinggi bila dibandingkan dengan kadar serat limbah pertanian lain. Seperti kulit biji kapas $(10,2 \%)$, bagas tebu $(9,6 \%)$, sekam $(6,3 \%)$ dan kulit kacang $(6,3)$ (Fengel dan Wegener, 2010). Oleh karena itu, limbah tonkol jagung berpotensi sebagai sumber bahan baku selulosa.

Selulosa adalah polimer dari $\beta$-glukosa dengan ikatan $\beta(1-4)$ antara unit-unit glukosa. Selulosa terdapat pada kayu, kapas, rami dan tumbuhan lainnya. Selulosa 
pertama kali diisolasi dari kayu pada tahun 1885 oleh Charles F. Cross dan Edward Bevan (Fennema dan Owen, 2010).

Seiring dengan perkembangan ilmu pengetahuan dan teknologi (Iptek) terutama mengenai bahan pembantu, pengisi dan pengembang, maka limbah lognoselulosa dapat lebih efisien digunakan dengan modifikasi, salah satunya untuk proses produksi menjadi selulosa mikrokristal sebagai bahan pembantu pembuatan obat.

Selulosa mikrokristal dibuat dengan cara hidrolisis terkontrol alfa selulosa, suatu pulp dari tumbuhan yang berserat dengan larutan asam mineral encer ( Belitz, dkk. 2009). Selulosa mikrokristal dapat diperoleh secara komersil dari berbagai kualitas dan merek dagang. Salah satu produk selulosa mikrokristal diperdagangan dikenal dengan merek dagang Avicel. Ada beberapa macam jenis avicel, salah satunya avicel PH 102 (Fennema dan Owen, 2010).

Tablet adalah bentuk sediaan yang paling banyak beredar karena secara fisik stabil, mudah dibuat, lebih menjamin kestabilan bahan aktif dibandingkan bentuk cair, mudah dikemas, praktis, mudah digunakan, homogen, dan reprodusibel. Massa tablet harus mengalir dengan lancar agar dapat menjamin homogenitas dan reprodusibilitas sediaan dan harus dapat terkompresi dengan baik agar diperoleh tablet yang kuat, kompak, dan stabil selama penyimpanan dan distribusi. (Lachman,Leon.1994)

Tablet dibuat dengan dua cara yaitu dengan cara granulasi dan cetak langsung. Cara granulasi dapat dilakukan dengan crara granulasi basah dan granulasi kering. Pada granulasi basah, bahan obat dan bahan pembantu (pengisi, pengikat dan pengembang) dicampur dan dibasahi dengan bahan pembasah kemudian dibuat dalam bentuk granul, granul tersebut dikeringkan. Granul yang telah kering menjadi free flowing, mengalir dengan kontiniu dan sempurna dari corong pengisi ke ruang cetak pada pencetakan tablet. Granulasi kering dibuat dengan dengan mengempa campuran bahan obat, pengisi, pengikat dan pengembang menjadi tablet yang besar (slug). Kemudian slug tersebut dipecah-pecah (digerus) menjadi granul yang siap untuk dicetak menjadi tablet. Tablet cetak langsung dimungkinkan jika bahan yang akan dicetak telah berbentuk granul atau kristal dan mempunyai daya alir yang baik. Selulosa mikrokrisatal telah mempunyai daya alir yang cukup, disamping itu selulosa mikrokristal mempunyai sifat dapat mengikat (adsorben). Selulosa mikrokristal dalam bahan pembantu pembuatan tablet cetak langsung berfungsi sebagai bahan pengisi, pengembang dan pengikat.

Secara garis besar, proses isolasi selulosa dari tongkol jagung dilakukan dalam 2 (dua) tahap, yaitu tahap maserasi dan tahap hidrolisis (Nishizawa, 2002). Pada tahap pertama senyawa lemak, protein dan metabolit sekunder diekstraksi dengan etanol. Selulosa dan hemiselulosa tidak larut dalam etanol hingga dapat dipisahkan dengan penyaringan. Residu hasil penyaringan dihidrolisa dengan asam klorida dengan berbagai konsentrasi untuk memisahkan selulosa dan hemiselulosa (Fennema dan Owen, 2010). Hidrolisa dengan asam klorid pada tahap kedua akan menentukan karakteristik selulosa yang dihasilkan (Nishizawa, 2002, Tranggono dkk., 1991).

\subsection{Rumusan Masalah}

1. Apakah selulosa mikrokristal yang diisolasi dari tongkol jagung memenuhi karakteristik sellulosa mikrokristal.

2. Pada konsentrasi berapa $\mathrm{HCl}$ yang digunakan pada hidrolisa untuk mendapatkan selulosa yang optimal.

3. Apakah tablet CTM yang dibuat menggunakan selulosa mikrokristal yang diisolasi dari tongkol jagung memenuhi persyaratan evaluasi tablet.

\subsection{Tujuan Penelitian}

1. Tujuan Umum Memanfaatkan limbah pertanian (tongkol jagung) hingga lebih berdayaguna.

2. Tujuan Khusus

a. Memanfaatkan potensi yang terkandung pada limbah tongkol jagung sebagai bahan baku pembuatan selulosa mikrokristal.

b. Mengetahui konsentrasi $\mathrm{HCl}$ yang optimal pada hidrolisa selulosa.

c. Untuk mengetahui apakah tablet klorfeniramin maleat yang dibuat menggunakan selulosa mikrokristal yang diperoleh dari isolasi dari tongkol jagung memenuhi persyaratan evaluasi tablet.

\subsection{Manfaat}

Produksi jagung di Sumatera Utara mengalami peningkatan, sehingga limbah tongkol jagung menjadi tinggi, sementara pemanfaatan dan pengolahan ditingkat petani masih sanyat terbatas. Penelitian ini merupakan salah satu alternative untuk menaikkan nilai ekonomi limbah tongkol jagung mengandung selulosa yang dapat diisolasi untuk dimanfaatkan sebagai bahan pembantu pembuatan obat.

\section{Desain dan Metodologi Penelitian 2.1 Desain Penelitian}

Penelitian ini dilakukan secara eksperimental meliputi pembuatan selulosa dari bahan dasar tongkol jagung dengan berbagai konsentrasi asam klorida pada hidrolisa. Selanjutnya diperiksa karakteristik selulosa yang dihasilkan meliputi, $\mathrm{pH}$, distribusi ukuran partikel, bobot jenis nyata, bobot jenis mampat, persen kompresibilitas, sifat alir, sudut diam dan kompaktibillitas. Tablet CTM dibuat dengan bahan pembantu selulosa mikrokristal dari tongkol jagung dan bahan pembantu Avicel. Tablet yang dihasilkan dievaluasi meliputi kekerasan, freabilitas, laju disolusi dan waktu hancur menurut Farmakope Indonesia Edisi IV, dibandingkan dengan tablet CTM yang beredar di pasar. Data evaluasi diuji dengan SPSS for Windos 16 dengan mencari nilai uji kesamaan rata-rata.

\subsection{Sampel}

Sampel yang digunakan dalam penelitin ini adalah tongkol jagung vareitas Arjuna yang diperoleh dari pemipilan jagung di Desa Tiga Binanga, Kabupaten Karo, yang diambil secara purposive, tanpa mempermasalahkan 
asal, daerah tumbuh dan kesuburannya, diambil secukupnya berdasarkan kebutuhan.

\subsection{Bahan}

Bahan yang digunakan dalam penelitian ini meliputi serbuk tongkol jagung, etanol, $\mathrm{HCl}$.

\subsection{Alat}

Alat yang digunakan meliputi mesin penggiling, ayakan ukuran mesh $25,35,40,50,70,100$ dan 140, neraca analitik, oven, eksikator, labu , corong, gelas kimia, gelas ukur, botol timbang, tanur, corong Buchner, pompa vacuum, mesin cetak tablet, $\mathrm{pH}$ meter, automatic garanule flaw tester, hardner tster, frabilator, desolution tester dan disintegration tester.

\subsection{Prosedur Kerja}

\subsubsection{Pembuatan Selulosa Mikrokristal}

\section{a. Pembuatan serbuk tongkol jagung}

Tongkol jagung dikeringkan diudara terbuka, kemudian digiling dan diayak dengan mesh 100. Tentukan kadar air dengan cara menimbang 2 gram $\left(\mathrm{W}_{1}\right)$ serbuk tongkol jagung dalam botol timbang, kemudian dimasukkan kedalam oven selama 4 jam pada suhu $105^{\circ} \mathrm{C}$, setelah itu dinginkan dalam eksikator dan timbang sampai berat tetap $\left(\mathrm{W}_{2}\right)$.

Kadar air $=\frac{\mathrm{W}_{1}-\mathrm{W}_{2}}{\mathrm{~W}_{1}} \mathrm{\text {--------- }}$

\section{b. Proses Maserasi (Nishizawa, 2002).}

Dua puluh (200) gram berat kering serbuk tongkol jagung dimasukkan kedalam beaker glas $3000 \mathrm{ml}$, tambahkan $500 \mathrm{ml}$ etanol, maserasi dilakukan selama 7 hari sampai larutan tidak lagi berwarna dengan menggantikan etanol setiap dua hari. Serkai dan saring, residu dikeringkan pada suhu $100^{\circ} \mathrm{C}$ selama 1 jam.

\section{c. Proses Hidrolisis (Liu dkk. 2011).}

Residu yang dihasilkan dimasukkan kedalam beaker glas $500 \mathrm{ml}$, tambahkan $100 \mathrm{ml}$ larutan $\mathrm{HCl}$ dengan variasi konsentrasi $1 \%, 3 \%, 5 \%, 7 \%, 9 \%$ dan $11 \%$ panaskan pada suhu $105^{\circ} \mathrm{C}$ selama 1 jam. Residu yang dihasilkan disaring kemudian dicuci dengan aquades hingga air cucian menjadi netral. Keringkan endapan pada suhu $100^{\circ} \mathrm{C}$ selama 2 jam. Dari bobot yang diperoleh dapat diketahui kemurnian selulosa mikrokristal.

\subsubsection{Karakteristik Selulosa Mikrokristal}

\section{a. Pengukuran pH ( Ditjen POM, 1979)}

Ditimbang 1 gram berat kering selulosa, ditambah 100 $\mathrm{ml}$ aquades kemudian dipanaskan sampai suhu $70^{\circ} \mathrm{C}$ sambil diaduk sampai larut dan setelah dingin diukur pHnya.

\section{b. Distribusi Ukuran Partikel}

Pemeriksaan distribusi ukuran partikel dilakukan dengan cara mengayak selulusa mikrokristal yang dihasilkan dengan pengayak mesh 25, 35, 40, 50, 70, 100 140. Timbang lima puluh gram granul lalu masukkan ke dalam pengayak. Kemudian jalankan alat dengan laju 30 getaran per detik selama 20 menit. Menghitung granul yang tertinggal pada pengayak, dengan cara mencari selisih antara berat pengayak dengan granul yang tertinggal di dalamnya dikurangi berat pengayak awal. Menghitung jumlah fines dengan cara mencari selisih antara berat granul awal dengan granul yang tertinggal di dalam pengayak.

\section{c. Penentuan Bobot Jenis Nyata}

Pemeriksaan bobot jenis nyata selulosa mikrokristal dari tongkol jagung dilakukan dengan cara gelas ukur $100,0 \mathrm{ml}$ kosong ditimbang (W1), campuran granulat diisikan melalui corong ke dalam gelas ukur sampai volume $100 \mathrm{ml}$ dan ditimbang (W2)

$$
\text { Bobot Jenis= } \begin{gathered}
\mathrm{W} 2-\mathrm{W} 1 \\
100
\end{gathered}
$$

Bobot jenis nyata yang didapat merupakan rata-rata dari tiga penentuan.

\section{d. Penentuan Bobot Jenis Mampat}

Pemeriksaan bobot jenis mampat selulosa mikrokristal dari tongkol jagung dapat dilakukan dengan cara serbuk dalam gelas ukur 100,0 ml (pemeriksaan bobot jenis nyata), diketuk-ketuk untuk menentukan bobot jenis mampat sampai terdapat volume konstan. Bobot jenis mampat dapat dihitung sebagai berikut:

$$
\begin{gathered}
\text { W2-W1 } \\
\text { Bobot Jenis Mampat=-------- g/ml } \\
\text { Vol. }
\end{gathered}
$$

Bobot jenis mampat, yang didapat merupakan ratarata dari tiga kali pengukuran.

\section{e. Pemeriksaan kompresibilitas}

Pemeriksaan kompresibilitas granul selulosa mikrokristal dari tongkol jagung dapat dihitung dengan cara sebagai berikut.

$$
\begin{gathered}
\text { bj.m }- \text { bj.n } \\
\text { bj.m }
\end{gathered}
$$

Ket. :

$$
\begin{aligned}
& \text { bj.m }=\text { bobt jenis mapat } \\
& \text { bj.n }=\text { bobot jenis nyata }
\end{aligned}
$$

\section{f. Pemeriksaan waktu alir dan sudut diam}

Sebanyal 100 gram granul dimasukkan ke dalam corong dimana bagian bawah corong ditutup. Waktu alir adalah waktu yang diperlukan oleh granul untuk megalir mulai dari dibukanya penutup bawah corong sampai habis. Sudut diam diukur dari kerucut yang dibentuk oleh massa granul, dengan rumus sebagai berikut. $\mathrm{h}$

$$
\tan \alpha=-----
$$

Ket.:

$$
\begin{aligned}
& \alpha=\text { sudut diam } \\
& \mathrm{h}=\text { tinggi kerucut }(\mathrm{cm}) \\
& \mathrm{r}=\text { jari-jari kerucut }(\mathrm{cm})
\end{aligned}
$$


Kecepatan alir granul yang baik jika lebih kecil dari $10 \mathrm{~g} / \mathrm{dt}$, dengan sudut diam antara $<25^{\circ}-40^{\circ}$.

\subsubsection{Pembuatan Tablet CTM}

Tablet CTM dibuat menurut komposisi Formularium Indonesia dengan komposisi satu tablet (1 dan 2) :

1. R/ Klorfeniramini meleat $4 \mathrm{mg}$ Selulosa Mikrokristal ad $200 \mathrm{mg}$ m.f. tab. dtd. No. D

2. $\mathrm{R} /$ Klorfeniramini maleat $4 \mathrm{mg}$ Avicel ad $200 \mathrm{mg}$ m.f. tab. dtd. No. D

\section{R/ CTM tablet No. D}

Pada formula 1 dan 2 masing masing bahan (klorfeniramini maleat dengan bahan pembantu) campur homogen kemudian masing-masing formula cetak langsung menjadi tablet. Tablet yang dihasilkan dan tablet CTM (3) dievaluasi dengan persyaratan tablet menurut Farmakope Indonesia Edisi IV meliputi, keseragaman bobot, kekerasan, feriabilitas dan laju desolusi.

\subsubsection{Uji persyaratan Tablet}

\section{a. Keseragaman Bobot}

Timbang 20 (duapuluh) tablet satu persatu, hitung bobot rata-rata satu tablet.

\section{b. Kekerasan Tablet}

Uji kekerasan dilakukan dengan mengambil masingmasing 10 tablet kemudian diukur kekerasannya dengan alat pengukur kekerasan tablet (Strong cobb hardness tester).

\section{c. Friabilitas}

Tablet yang akan diuji sebanyak 20 tablet, terlebih dahulu dibersihkan dari debunya dan ditimbang dengan seksama. Tablet tersebut selanjutnya dimasukkan ke dalam friabilator, dan diputar sebanyak 100 putaran selama 4 menit, jadi kecepatan putarannya 25 putaran per menit. Setelah selesai, keluarkan tablet dari alat, bersihkan dari debu dan timbang dengan seksama. Kemudian dihitung persentase kehilangan bobot sebelum dan sesudah perlakuan.

\section{d. Laju Disolusi}

Alat yang digunakan adalah disolution tester, berbentuk dayung dengan media $500 \mathrm{ml}$ air. Masukkan 1 tablet kedalam wadah, hilangkan gelembung dari sediaan yang diuji dan segera jalankan alat dengan laju putaran 50 rpm. Setiap 5 menit diambil 5,0 ml larutan desolusi didaerah bagian tengah antara dayung. Setiap pengambilan media disolusi diganti kembali, sehingga volume media tetap $500 \mathrm{ml}$. Encerkan cuplikan yang diambil dengan $\mathrm{HCl}$ $3 \mathrm{~N}$ sampai volume $50,0 \mathrm{ml}$ kemudian ukur resapan pada spektrofotometri dengan panjang gelombang $262 \mathrm{~nm}$, dengan baku pembanding Kloramfeniramin Maleat BPFI

\section{e. Waktu Hancur}

Alat yang digunakan adalah disintegration tester, yang berbentuk keranjang, mempunyai 6 tube plastik yang terbuka dibagian atas, sementara dibagian bawah dilapisi dengan ayakan/screen no.10 mesh (Niazi and Sarfaraz,2009).

Tablet yang akan diuji (sebanyak 6 tablet) dimasukkan masing-masing satu tablet dalam tiap tube, ditutup dengan penutup dan dinaik-turunkan keranjang tersebut dalam medium air dengan suhu $37^{\circ} \mathrm{C}$ dengan kecepatan $30 \mathrm{kali}$ per menit. Waktu hancur dihitung berdasarkan tablet yang paling terakhir hancur.

\section{Hasil dan Pembahasan}

\subsection{Isolasi selulosa dari tongkol jagung.}

Secara umum, tumbuhan berkayu termasuk tongkol jagung terdiri dari ikatan-ikatan polimer selulosa dan hemiselulosa yang direkatkan oleh lignin. Disamping selulosa, pada tongkol jagung terdapat lemak, protein dan metabolit sekunder. Maserasi berulang-ulang dengan pelarut polar efektif memisahkan fraksi tersebut dari selulosa dan hemiselulosa. Lemak, protein dan metabolit sekunder dari tongkol jagung akan larut dalam etanol, sedangkan residu berupa selulosa dan hemiselulosa (Nishizawa, 2002).

Tabel 4.1. Hasil isolasi dan hidrolisa Serbuk Tongkol Jagung

\begin{tabular}{|c|c|c|c|c|c|c|}
\hline \multirow{2}{*}{ No } & \multirow{2}{*}{$\begin{array}{c}\% \\
\mathrm{HCl}\end{array}$} & \multirow{2}{*}{$\begin{array}{l}\text { Tongkol } \\
\text { Jagung } \\
(g)\end{array}$} & \multicolumn{2}{|c|}{ Hasil Ekstraksi } & \multicolumn{2}{|c|}{ Selulosa } \\
\hline & & & (g) & $(\%)$ & (g) & $(\%)$ \\
\hline \multirow{3}{*}{1} & \multirow{3}{*}{$1 \%$} & 201.7712 & 148.8164 & 73.76 & 107.67 & 58.32 \\
\hline & & \pm & \pm & \pm & \pm & \pm \\
\hline & & 1.27314 & 0.7588 & 0.28 & 0.7241 & 0.31 \\
\hline \multirow{3}{*}{2} & \multirow{3}{*}{$3 \%$} & 201.2488 & 148.7769 & 73.93 & 107.4669 & 53.4 \\
\hline & & \pm & \pm & \pm & \pm & \pm \\
\hline & & 0.8882 & 0.2780 & 0.33 & 0.1284 & 0.26 \\
\hline \multirow{3}{*}{3} & \multirow{3}{*}{$5 \%$} & 201.5988 & 148.4624 & 73.64 & 99.4959 & 49.39 \\
\hline & & \pm & \pm & \pm & \pm & \pm \\
\hline & & 1.0648 & 0.7845 & 0.31 & 0.2197 & 0.32 \\
\hline \multirow{3}{*}{4} & \multirow{3}{*}{$7 \%$} & 201.4738 & 148.3683 & 73.64 & 88.9583 & 44.15 \\
\hline & & \pm & \pm & \pm & \pm & \pm \\
\hline & & 0.7355 & 0.2548 & 0.31 & 0.6322 & 0.29 \\
\hline \multirow{3}{*}{5} & \multirow{3}{*}{$9 \%$} & 201.2670 & 148.2107 & 73.64 & 88.4420 & 43.94 \\
\hline & & \pm & \pm & \pm & \pm & \pm \\
\hline & & 0.5124 & 0.5573 & 0.31 & 0.1113 & 0.13 \\
\hline \multirow{3}{*}{6} & \multirow{3}{*}{$11 \%$} & 201.1232 & 148.1232 & 73.65 & 88.0809 & 43.79 \\
\hline & & \pm & \pm & \pm & \pm & \pm \\
\hline & & 0.5618 & 0.6821 & 0.25 & 0.4328 & 0.33 \\
\hline
\end{tabular}

Isolasi menggunakan etanol cukup memakan waktu yang lama (14 hari) dengan berulang-ulang mengganti etanaol sampai diperoleh hasil ekstraksi yang jerinih (tidak berwarna).

Selanjutnya dilakukan hidrolisa untuk memisahkan selulosa dan hemiselulosa. Pada tahap ini dilakukan proses 
pengasaman agar proses pemisahan selulosa dapat efektif dengan variasi asam klorida 1\%, 3\%, 5\%, 7\%, 9\% dan $11 \%$. Hidrolisa dengan pemanasan mempercepat pemisahan selulosa. Hasil ekstraksi kemudian dicuci dan dikeringkan hingga bobot tetap. Jumlah selulosa hasil ekstraksi dengan variasi asam dapat dilihat pada Table 4.1.

Dari hasil statistik (Tabel 4.2) selulosa yang dihasilkan dengan menggunakan konsentrasi $\mathrm{HCl} 7 \%, 9 \%$ dan $11 \%$ tidak ada perbedaan yang bermakna $(\alpha=0.05)$. Konsentrasi $\mathrm{HCl} 7 \%$ memberikan hasil yang optimal, kadar selulosa yang dihasilkan dari tongkol jagung adalah $44,15 \%$. Pada litratur (Fengel dan Wegener, 2010) kadar selulosa tongkol jagung 44,99\%.

Tabel 4.2 Hasil uji beda rata-rata Duncan terhadap hasil isolasi dan hidrolisa Serbuk Tongkol Jagung

\begin{tabular}{|c|c|c|c|c|c|c|}
\hline \multicolumn{2}{|c|}{ Hasil Selulosa } & \multirow{2}{*}{$\mathrm{N}$} & \multicolumn{4}{|c|}{ Subset for alpha $=0.05$} \\
\hline & & & 1 & 2 & 3 & 4 \\
\hline \multirow[t]{7}{*}{$\overline{\text { Duncan }^{\mathrm{a}}}$} & $\mathrm{HCl} 11 \%$ & 6 & 88.430 & & & \\
\hline & $\mathrm{HCl} 9 \%$ & 6 & 88.442 & & & \\
\hline & $\mathrm{HCl} 7 \%$ & 6 & 88.958 & & & \\
\hline & $\mathrm{HCl} 5 \%$ & 6 & & 99.495 & & \\
\hline & $\mathrm{HCl} 3 \%$ & 6 & & & 107.466 & \\
\hline & $\mathrm{HCl} 1 \%$ & 6 & & & & 117.67 \\
\hline & Sig. & & 0.060 & 1.000 & 1.000 & 1.000 \\
\hline
\end{tabular}

Penurunan kadar yang diperoleh dapat disebabkan pengguanan $\mathrm{HCl}$ yang berlebih. Makin tinggi kadar $\mathrm{HCl}$ yang digunakan dan lamanya pemanasan mempengaruhi jumlah selulosa yang dihasilkan. Penggunaan $\mathrm{HCl}$ yang lebih pekat tidak hanya mempermudan melarutkan hemiselulosa tapi selulosa dapat juga terhidrolisa menjadi fraksi-fraksi monosakarida (glukosa dan fruktosa) dalam suasana asam yang pekat. Halini dapat terlihat pada penggunaan $\mathrm{HCl} 9 \%$ dan $11 \%$, selulosa yang dihasilkan mengalami penurunan, tapi secara statistic tidak bermakna $(\alpha=0.05)$.

\subsection{Karateristik Selulosa Tongkol Jagung}

3.2.1 pH.

Tabel 3.1 Perbandingan pH Selulosa Tongkol Jagung dengan Avicel.

\begin{tabular}{ccc}
\hline & \multicolumn{2}{c}{$\mathrm{pH}$} \\
\cline { 2 - 3 } No & $\begin{array}{c}\text { Selulosa Tongkol } \\
\text { Jagung }\end{array}$ & Avicel \\
\hline 1 & 6.953 & 7.004 \\
2 & 6.961 & 7.012 \\
3 & 6.955 & 7.025 \\
4 & 7.010 & 7.008 \\
5 & 7.014 & 7.006 \\
6 & 7.012 & 7.009 \\
\hline Rerata & 6.9842 & 7.0107 \\
\hline SD & 0.0280 & 0.0069 \\
\hline
\end{tabular}

Jika dibandingkan $\mathrm{pH}$ Selulosa Tongkol Jagung dengan selulosa hasil industri (Avicel yang diproduksi
Merck) terlihat $\mathrm{pH}$ Selulosa Tongkol Jagung lebih rendah (Tabel 3.1).

Halini disebabkan proses pembuatan Selulosa Tongkol Jagung mengunakan asam sebagai bahan hidrolisa. Pencucian yang telah dilakukan berulang-ulang tidak membebaskan asam secara murni. Tapi batas $\mathrm{pH}$ yang diizinkan sebagai bahan pembantu pembuatan tablet telah memenuhi syarat.

\subsubsection{Distribusi Ukuran Partikel}

Ukuran partikel akan mempengaruhi waktu alir granul atau serbuk. Waktu alir akan mempengaruhi pengisian ruang cetak pada pembuatan tablet. Kecepatan pengisian ruang cetak akan mempengaruhi keseragaman bobot tablet yang akan dicetak (Siregar, dkk., 2008). Ukuran partikel yang dihasilkan selulosa yang diperoleh dari tongkol jagung tergantung pada granulasi basah hasil hidrolisa selulosa. Granulasi basah selulosa tongkol jagung digunakan ayakan 80, sama seperti ukuran partikel Avicel

\subsubsection{Penentuan Bobot Jenis Nyata dan Bobot Jenis Mampat}

Bobot jenis nyata selulosa tongkol jagung sedikit lebih ringan bila dibanding dengan bobot jenis nyata Avicel. Tetapi bobot jenis mampat tidak menujukkan perbedaan yang nyata. Bobot jenis nyata dan bobot jenis mampat selulosa tongkol jagung dan Avicel dapat dilihat pada Tabel 3.2

Tabel 3.2 Bobot Jenis Nyata dan Bobot Jenis Mampat Selulosa Tongko Jagung dan Avicel

\begin{tabular}{|c|c|c|c|c|c|c|}
\hline \multirow{5}{*}{ No. } & \multicolumn{2}{|c|}{ Bobot Jenis Nyata } & \multirow{2}{*}{\multicolumn{4}{|c|}{ Bobot Jenis Mampat }} \\
\hline & \multicolumn{2}{|c|}{$(\mathrm{g} / \mathrm{ml})$} & & & & \\
\hline & \multirow{3}{*}{$\begin{array}{c}\text { Selulosa } \\
\text { Tongkol } \\
\text { Jagung }\end{array}$} & \multirow{3}{*}{ Avicel } & \multicolumn{2}{|c|}{ Selulosa } & \multirow{2}{*}{\multicolumn{2}{|c|}{ Avicel }} \\
\hline & & & \multicolumn{2}{|c|}{ Tongkol Jagung } & & \\
\hline & & & $(\mathrm{g} / \mathrm{ml})$ & $(\%)$ & $(\mathrm{g} / \mathrm{ml})$ & $(\%)$ \\
\hline 1 & 0.991 & 1.0034 & 0.983 & 0.85 & 0.992 & 0.83 \\
\hline 2 & 0.988 & 1.0030 & 0.984 & 0.86 & 0.997 & 0.84 \\
\hline 3 & 0.999 & 1.0032 & 0.983 & 0.85 & 0.989 & 0.85 \\
\hline 4 & 0.995 & 1.0054 & 0.984 & 0.86 & 0.996 & 0.84 \\
\hline 5 & 0.993 & 1.0008 & 0.983 & 0.85 & 0.996 & 0.85 \\
\hline 6 & 0.994 & 1.0034 & 0.984 & 0.86 & 0.995 & 0.84 \\
\hline Rerata & 0.994 & 1.0032 & 0.9835 & 0.855 & 0.9942 & 0.841 \\
\hline SD & 0.0034 & 0.0013 & 0.0005 & 0.006 & 0.0028 & 0.007 \\
\hline
\end{tabular}

\subsubsection{Pemeriksaan waktu alir dan sudut diam}

Waktu alir merupakan waktu yang digunakan untuk mengalir dari sejumlah granul atau serbuk pada alat yang dipakai. Mudah tidaknya granul mengalir dipengaruhi oleh bentuk granul, sifat permukaan granul, density, dan kelembapan granul. Menurut Lachman, et al., (1994) untuk $100 \mathrm{~g}$ granul atau serbuk dengan waktu alir lebih dari 10 detik akan mengalami kesulitan dalam penabletan. 
Tabel 3.3 Waktu Alir dan Sudut Diam Selulosa Tongkol Jagung dan Avicel

\begin{tabular}{|c|c|c|c|c|}
\hline \multirow{3}{*}{ No. } & \multicolumn{2}{|c|}{$\frac{\text { Waktu Alir }}{\text { (detik) }}$} & \multicolumn{2}{|c|}{ Sudut Diam } \\
\hline & Selulosa & & Selulosa & \\
\hline & $\begin{array}{l}\text { Tongkol } \\
\text { Jagung }\end{array}$ & Avicel & $\begin{array}{c}\text { Tongkol } \\
\text { Jagung }\end{array}$ & Avicel \\
\hline 1 & 8.3 & 8.2 & 33 & 32 \\
\hline 2 & 8.3 & 8.2 & 32 & 32 \\
\hline 3 & 8.2 & 8.3 & 33 & 33 \\
\hline 4 & 8.3 & 8.3 & 33 & 34 \\
\hline 5 & 8.2 & 8.2 & 34 & 34 \\
\hline 6 & 8.3 & 8.2 & 33 & 33 \\
\hline Rerata & 8.2667 & 8.23 & 33.00 & 33.00 \\
\hline SD & 0.0471 & 0.0471 & 0.5774 & 0.8165 \\
\hline
\end{tabular}

Waktu alir dan sudut diam selulosa tongkol jagung dan Avicel tidak ada perbedaan yang bermakna. Hal ini disebabkan karena bobot jenis dan ukuran partikel antara selulosa tongkol jagung dan Avicel hampir bersamaan. Jika bobot jenis dan ukuran partikel serbuk sama maka waktu alir dan sudut diamnya sama (Lachman, et al., 1994). Waktu alir dan sudut diam selulosa tongkol jagung dan Avisel dapat dilihat pada Tabel 3.3.

\subsection{Pembuatan Tablet CTM}

Tablet CTM dibuat masing-masing menggunakan bahan pembantu Selulosa Tongkol Jagung dan Avicel.
1. $\mathrm{R} /$ Chlorfeniramin maleat $2 \mathrm{~g}$
Selulosa Tongkol Jagung $\quad 98 \mathrm{~g}$ m.f.tab. No.D
2. $\mathrm{R} /$ Chlorfeniramin maleat $2 \mathrm{~g}$ Avicel $\quad 98 \mathrm{~g}$ m.f.tab. No.D

Masing-masing formula dicetak menjadi tablet, ternyata Tablet CTM dengan bahan pembantu selulosa tongkol jagung diperoleh 460 tablet sedangkan tablet CTM dengan bahan pembantu Avicel diperoleh sebanyak 472 tablet. Perbedaan jumlah tablet yang dihasilkan disebabkan oleh bobot satu tablet dengan tablet lainnya tidak persis sama. Rata-rata bobot satu tablet CTM dengan bahan pembantu selulosa tongkol jagung adalah 0,2043 g sedangkan bobot rata-rata tablet CTM dari Avicel adalah $0.2026 \mathrm{~g}$

\subsection{Evaluasi Tablet}

Tablet CTM yang diproleh dengan bahan pembantu selulosa tongkol jagung, tablet CTM dengan bahan pembantu Avicel dan tablet CTM yng telah beredar di pasar yang diproduksi PT. Pharmacetical Laboratorium, Jakarta yang diperolel dari Apotik, dibandingkan persyaratan tablet sesuai dengan Farmakope Indonesia IV (Ditjen POM, 1995).

\subsubsection{Keseragaman Bobot Tablet}

Tabel 3.4 Persyaratan Keseragaman Bobot Tablet (Ditjen POM, 1995)

\begin{tabular}{lcc}
\hline \multirow{2}{*}{ Bobot Tablet } & \multicolumn{2}{c}{$\begin{array}{c}\text { Penyimpangan bobot rata-rata } \\
(\%)\end{array}$} \\
\cline { 2 - 3 } & $\mathrm{A}$ & $\mathrm{B}$ \\
\hline $25 \quad \mathrm{mg}$ atau & & 30 \\
kurang & 15 & 20 \\
$26 \mathrm{mg}-150 \mathrm{mg}$ & 10 & 15 \\
$151 \mathrm{mg}-300 \mathrm{mg}$ & 7.5 & 10 \\
$300 \mathrm{mg} \mathrm{atau}$ lebih & 5 & \\
\hline
\end{tabular}

Menurut Farmakope Indonesia IV (Ditjen POM, 1995), keseragaman bobot ditentukan berdasarkan ada atau tidaknya penyimpangan bobot yang dihasilkan terhadap bobot rata-rata tablet.

Tablet yang tidak bersalut harus memenuhi syarat keseragaman bobot yang ditetapkan sebagai berikut : untuk 20 tablet dihitung bobot rata-ratanya, jika ditimbang satu persatu, tidak boleh lebih dari jumlah masing-masing bobotnya menyimpang dari bobot rata-ratanya lebih besar dari harga yang ditetapkan di kolom A dan tidak satupun tablet yang bobotnya menyimpang dari bobot rata-ratanya lebih dari harga yang ditetapkan dikolom B (Tabel 3.4).

Tablet CTM dengan bahan pembantu selulosa, Avicel dan tablet CTM produksi PT. Pharmaceuticl Laboratorium dengan bobot rata-rata berturut- turut 0.2042 $\mathrm{mg} \pm 0.0030 \mathrm{mg}, 0,2026 \mathrm{mg} \pm 0,0029$ dan $0.1820 \mathrm{mg} \pm$ $0.031 \mathrm{mg}$ (Tabel 4.7) telah memenuhi syarat keseragaman bobot tablet (Ditjen POM, 1995). Tidak ada tablet yang menyimpang dari kolom A maupun kolom B. Hal ini menunjukkan bahwa, waktu alir, perbandingan granul selulosa maupun Avicel dengan fines (Clorfeniramin maleat) telah memenuhi syarat untuk dijadikan bahan pembantu tablet cetak langsung (Niazi and Sarfaraz, 2009).

Tidak ada perbedaan yang bermakna $(\alpha=0.05)$ antara bobot rata-rata tablet CTM dengan bahan pembantu selulosa tongkol jagung dan tablet CTM dengan bahan pembantu Avicel, seperti terlihat pada Tabel 3.5.

Tabel 3.5 Hasil uji beda rata-rata Duncan terhadap bobot rata-rata tablet

\begin{tabular}{|c|c|c|c|c|c|}
\hline \multirow{2}{*}{\multicolumn{3}{|c|}{ Tablet CTM }} & \multirow[b]{2}{*}{$\mathrm{N}$} & \multicolumn{2}{|c|}{ Subset for alpha $=0.05$} \\
\hline & & & & 1 & 2 \\
\hline \multirow{7}{*}{$\begin{array}{l}\text { Dunc } \\
\mathrm{an}^{\mathrm{a}}\end{array}$} & Produks & PT. & & & \\
\hline & Pharmace & & 20 & 0.1820 & \\
\hline & Laborator & & & & \\
\hline & $\begin{array}{l}\text { Bahan } \\
\text { Avicel }\end{array}$ & & 20 & & 0.2026 \\
\hline & Bahan & pembantu & & & \\
\hline & $\begin{array}{l}\text { Selulosa } \\
\text { Jagung }\end{array}$ & Tongkol & 20 & & 0.2042 \\
\hline & Sig. & & & 1 & 0.097 \\
\hline
\end{tabular}


Perbedaan bobot tablet CTM produksi PT Pharmaceutical Laboratorium dengan tablet CTM dengan bahan pembantu selulosa tongkol jagung dan Avicel terletak pada alat pencetak (punch dan die) yang digunakan (Lachman, et al.,1994). Punch dan die yang digunakan oleh pabrik PT. Pharmaceutical lebih kecil volumenya dibanding punch dan die yang digunakan pada pencetakan tablet CTM selulosa tongkol jagung dan Avicel.

\subsubsection{Kekerasan Teblet}

Tablet harus mempunyai kekuatan atau kekerasan tertentu serta tahan atas kerapuhan agar dapat bertahan terhadap berbagai guncangan mekanik pada saat pembuatan, pengepakan, dan pengiriman (Lachman and Lieberman, 2004). Kekerasan digunakan sebagai parameter tekanan mekanik dari tekanan pengempaan dan dipengaruhi juga oleh kemampuan daya ikat bahan pembantu pembuatan tablet. Kekerasan tablet yang dibuat akan mempengaruhi frabilitas dan waktu hancur tablet. Tablet yang kekerasannya kecil akan mudah hancur, terutama pada pendistribusian dari pabrik ketempat pelayan kefarmasian. Tablet yang sangat keras akan mempengaruhi waktu hancur tablet tersebut pada lambung. Kekerasan tablet pada umumnya $1-5$ kP (Niazi, and Sarfaraz, 2009). Tablet CTM dengan bahan pembantu selulosa tongkol jagung dan bahan pembantu Avicel dibuat dengan mesin pencetak dan tekanan yang sama. Ini menunjukan bahwa kemampuan mengikat selulosa tongkol jagung tidak berbeda dengan bahan pembantu Avicel (Tabel 3.6).

Tabel 3.6 Kekerasan tablet

\begin{tabular}{cccc}
\hline \multirow{2}{*}{ Tab. No } & \multicolumn{3}{c}{ Kekerasan Tablet CTM dengan bahan pembantu } \\
\cline { 2 - 4 } & $\begin{array}{c}\text { Selulosa } \\
\text { Tongkol } \\
\text { Jagung }\end{array}$ & Avicel & $\begin{array}{c}\text { Produksi PT. } \\
\text { Pharmaceutical } \\
\text { Laboratorium }\end{array}$ \\
\hline 1 & 4.16 & 4.19 & 4.66 \\
2 & 4.18 & 4.23 & 4.68 \\
3 & 4.20 & 4.16 & 4.67 \\
4 & 4.15 & 4.16 & 4.56 \\
5 & 4.18 & 4.20 & 4.65 \\
6 & 4.20 & 4.21 & 4.78 \\
7 & 4.15 & 4.18 & 4.56 \\
8 & 4.19 & 4.16 & 4.89 \\
9 & 4.22 & 4.15 & 4.67 \\
10 & 4.19 & 4.19 & 4.57 \\
\hline Rerata & 4.18 & 4.18 & 4.67 \\
\hline SD & 0.023 & 0.026 & 0.103 \\
\hline Ken
\end{tabular}

Keterangan:

STJ = Tablet CTM selulosa Tongkol Jagung

Avicel $=$ Tablet CTM Avicel

PT.PL $=$ Tablet CTM produksi PT.Pharmaceutikal Laboratorium

Tidak ada perbedaan yang nyata $(\alpha=0.05)$ kekerasan tablet CTM bahan pembantu selulosa tongkol jagung dengan kekerasan tablet CTM bahan pembantu Avicel (Tabel 3.7).
Tabel 3.7 Hasil uji beda rata-rata Duncan terhadap kekerasan tablet.

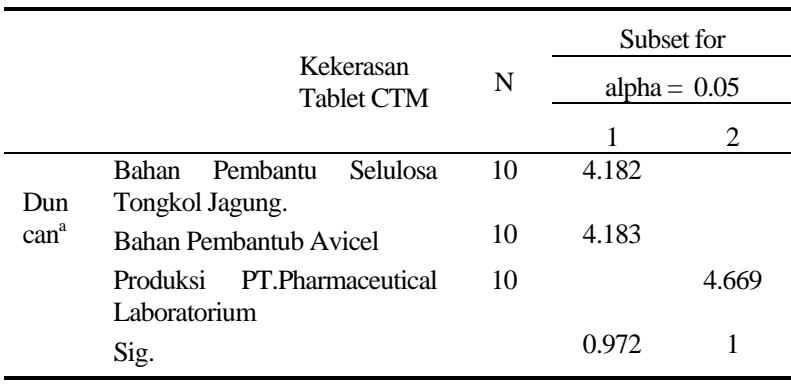

Kekerasan tablet CTM produksi PT. Pharmaceutical Laboratorium lebih keras bila dibanding dengan tablet CTM dengan bahan pembantu selulosa tongkol jagung dan tablet CTM bahan pembatu Avice. Tablet CTM produksi PT. Pharmaceutical Laboratorium menggunakan bahan pengikat tambahan dan dicetak dengan mesin cetak tablet yang berbeda dengan tablet CTM selulosa tongkol jagung dan tablet CTM Avicel. Kekerasan tablet diatur dengan memberikan tekanan pada panch mesin pencetak tablet (Niazi and Sarfaraz, 2009).

\subsubsection{Friabilitas}

Kerapuhan adalah parameter lain dari ketahanan tablet dalam pengikisan dan guncangan. Besaran yang dipakai adalah persen bobot yang hilang selama pengujian dengan alat friabilator. Faktor-faktor yang mempengaruhi kerapuhan antara lain banyaknya kandungan serbuk (fines), daya ikat bahan pembantu. Kerapuhan di atas 1,0\% menunjukkan tablet yang rapuh dan dianggap kurang baik (Niazi, and Sarfaraz, 2009).

Tabel 3.8 Freabilitas tablet CTM dengan bahan pembantu selulosa tongkol jagung, Avicel dan Tablet CTM PT.Pharmaceutical Laboratorium.

\begin{tabular}{cccc}
\hline \multirow{2}{*}{ Perlakuan } & \multicolumn{3}{c}{ Friabilitas tabel (\%) } \\
\cline { 2 - 4 } & STJ & Avicel & PT.PL \\
\hline 1 & 0.022 & 0.017 & 0.005 \\
2 & 0.012 & 0.020 & 0.005 \\
3 & 0.022 & 0.020 & 0.005 \\
4 & 0.015 & 0.017 & 0.005 \\
5 & 0.017 & 0.025 & 0.005 \\
6 & 0.022 & 0.012 & 0.019 \\
\hline Rerata & 0.018 & 0.018 & 0.008 \\
\hline SD & 0.004 & 0.004 & 0.005 \\
\hline Keterangan & & &
\end{tabular}

Keterangan:

STJ= Tablet CTM bahan pembantu selulosa tongkol jagung

Avicel $=$ Tabel CTM bahan pembantu Avicel

PT.PL = Tablet CTM Produksi PT. Pharmaceutical Laboratorium

Tabel 3.8 menunjukkan freabilitas tablet CTM dengan bahan selulosa tongkol jagung, tablet CTM dengan bahan Avicel dan tablet CTM produksi PT.Pharmaceutical Laboratorium. Pada pengujian tidak ada tablet yang pecah atau retak, hal ini menunjukkan bahwa selulosa tongkol jagung mampu mengikat 
frahmen dan bersatu dengan bahan berkhasiat clorfeniramin maleat dalam tablet CTM tersebut.

Tidak ada perbedaan yang nyata $(\alpha=0.05)$ freabilitas tablet CTM bahan pembantu selulosa tongkol jagung dengan tablet CTM Avicel (Tabel 3.9). Kemampuan daya ikat selulosa tongkol jagung dengan Avicel diperkirakan sama karena kedua bahan tersebut diperoleh dari selulosa tumbuhan (Adel, et.al.,2011)

Tabel 3.9 Hasil uji beda rata-rata Duncan terhadap Freabilitas tablet

\begin{tabular}{|c|c|c|c|c|}
\hline \multicolumn{2}{|c|}{ Tablet CTM } & \multirow[t]{2}{*}{$\mathrm{N}$} & \multicolumn{2}{|c|}{$\begin{array}{c}\text { Subset for alpha }= \\
0.05\end{array}$} \\
\hline & & & 1 & 2 \\
\hline \multirow[t]{4}{*}{$\begin{array}{l}\text { Dunc } \\
\text { an }^{\mathrm{a}}\end{array}$} & $\begin{array}{l}\text { Produksi PT.Pharmaceutical } \\
\text { Laboratorium }\end{array}$ & 6 & 0.0073 & \\
\hline & $\begin{array}{l}\text { Bahan pembantu selulosa } \\
\text { tongkol jagung }\end{array}$ & 6 & & 0.0183 \\
\hline & Bahan pembantu Avicel & 6 & & 0.0185 \\
\hline & Sig. & & 1 & 0.953 \\
\hline
\end{tabular}

\subsubsection{Laju Disolusi}

Laju desolusi suatu tablet merupakan persyaratan Farmakope Indonesia IV (Ditjen POM, 1995), merupakan Pharmaceutical Availiaility sediaan tablet. Kecepatan melarutnya bahan berhasiat tergantung pada kelarutan bahan berhasiat dan mudah lepasnya bahan berkhasiat dari bahan pembantu tablet (Lachman and Lieberman, 2004). Kecepatan melarutnya bahan berkhasiat juga tergantung pada waktu hancur, yang dipengaruhi oleh bahan pengikat dan kekerasan tablet (Marais, at all., 2003). Ketentuan Farmakope Indonesia IV untuk laju desolusi tablet CTM toleransi (Q) $75 \%$ dalam waktu 45 menit. Artinya tablet CTM yang memenuhi syarat harus larut $75 \%$ dalam waktu 45 menit.

Konsentrasi kelarutan clorfeniramin maleat dalam tablet ditentukan dengan Spektrofotometri UV dengan pelarut air pada panjang gelombang $262 \mathrm{~nm}$.

Kelarutan bahan berkhasiat dari tablet CTM selulosa tongkol jagung, tablet CTM Avicel dan tablet produksi PT. Pharmaceutical Laboratorium dapat dilihat pada Tabel 3.10 .

Kelarutan bahan berkhasiat tablet CTM dengan bahan bantu selulosa tongkol jagung dan tablet CTM Avicel tidak menunjukkan perbedaan yang nyata $(\alpha=$ 0.005), hal ini dapat dilihat dari Tabel 3.11, uji beda rata-rata Duncan terhadap persentasi kelarutran bahan berkhasiat dalam tablet CTM. Pelepasan clorfeniramin maleat oleh selulosa tongkol jagung maupun Avicel cukup baik, tidak mempengaruhi kelarutan clorfeniramin maleat dari tablet CTM.
Tabel 3.10. Persentasi Kelarutan Bahan Berkhasiat dari Tablet dalam wktu 45 menit

\begin{tabular}{cccc}
\hline \multirow{2}{*}{ Perlakuan } & \multicolumn{3}{c}{ Kadar terlarut (\%) } \\
\cline { 2 - 4 } & STJ & Avicel & PT.PL \\
\hline 1 & 80.300 & 78.075 & 75.575 \\
2 & 78.350 & 78.575 & 73.625 \\
3 & 78.900 & 80.525 & 71.900 \\
4 & 75.850 & 76.425 & 78.300 \\
5 & 78.350 & 77.900 & 77.550 \\
6 & 77.750 & 78.100 & 74.500 \\
Rerata & 78.250 & 78.2667 & 75.2417 \\
SD & 1.4598 & 1.3256 & 2.4134 \\
\hline
\end{tabular}

Keterangan:

STJ= Tablet CTM bahan pembantu selulosa tongkol jagung

Avicel = Tabel CTM bahan pembantu Avicel

PT.PL = Tablet CTM Produksi PT. Pharmaceutical Laboratorium

Tabel 3.11 Hasil beda rata-rata Duncan terhadap persentasi kelarutan bahan berkhasiat dalam tablet

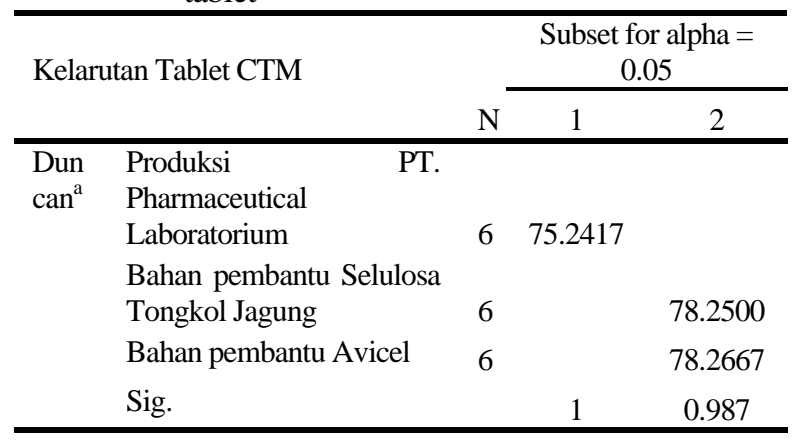

Persentasi kelarutan clorfeniramin maleat dalam tablet CTM produksi PT. Pharmaceutical Laboratorium lebih kecil dari persentasi kelarutan clorfeniramin maleat dalam tablet CTM selulosa tongkol jagung dan tablet CTM Avicel disebabkan karena tablet CTM produksi PT. Pharmaceutical Laboratorium menggunakan bahan tambahan pengikat, hal ini dapat terlihat pada kekerasan dan waktu hancur tablet CTM produksi PT. Pharmacetical Laboratorium lebih besar dari tablet CTM dengan bahan pembantu selulosa tongkol jagung atau Avicel tanpa bahan pengikat tambahan.

\section{Waktu Hancur}

Waktu hancur adalah waktu yang dibutuhkan sejumlah tablet untuk hancur menjadi granul/partikel penyusunnya yang mampu melewati ayakan no.10 yang terdapat dibagian bawah alat uji

Faktor-faktor yang mempengaruhi waktu hancur suatu sediaan tablet yaitu sifat fisik granul, kekerasan, porositas tablet, dan daya serap granul. Penambahan tekanan pada waktu penabletan menyebabkan penurunan porositas dan menaikkan kekerasan tablet. Dengan bertambahnya kekerasan tablet akan menghambat penetrasi cairan ke dalam pori-pori tablet sehingga memperpanjang waktu hancur tablet (Lachman dan Lieberman, 2004). Kecuali dinyatakan lain waktu hancur tablet bersalut tidak > 15 menit (Ditjen POM, (1995). 
Tabel 3.12 Waktu Hancur Tablet CTM Selulosa Tongkol Jagung, Tablet CTM Avicel dan Tablet CTM Produksi PT. Pharmaceutical Laboratorium

\begin{tabular}{cccc} 
& Produksi PT. Pharmaceutical Laboratorium \\
\cline { 2 - 4 } Perlakuan & \multicolumn{2}{c}{ Waktu hancur Tablet CTM (menit) } \\
\cline { 2 - 4 } & $\begin{array}{c}\text { Selulosa } \\
\text { Tongkol } \\
\text { Jagung }\end{array}$ & Avicel & $\begin{array}{c}\text { Produksi PT. } \\
\text { Pharmaceutical } \\
\text { Laboratorium }\end{array}$ \\
\hline 1 & 8 & 8 & 12 \\
2 & 9 & 8 & 11 \\
3 & 8 & 9 & 14 \\
4 & 8 & 9 & 15 \\
5 & 9 & 8 & 12 \\
6 & 9 & 8 & 14 \\
\hline Rerata & 8.5 & 8.33 & 13 \\
\hline SD & 0.55 & 0.52 & 1.55 \\
\hline
\end{tabular}

Waktu hancur tablet CTM dengan bahan pembantu selulosa tongkol jagung, tablet CTM bahan pembantu Avicel dan tablet CTM produksi PT. Pharmaceutical Laboratorium memenuhi syarat Farmakope Indonesia IV (Ditjen POM, 1995) (Tabel 3.12). Waktu hancur tablet CTM produksi PT. Pharmaseutical Laboratorium lebih lama dibanding dengan tablet CTM dengan bahan pembantu selulosa tongkol jagung dan tablet CTM bahan pembantu Avicel. Tablet CTM produksi PT. Pharmaceutical Laboratorium menggunakan bahan pengikat sehingga kekerasan dan waktu hancur menjadi lama.

Selulosa tongkol jagung dan Avicel cukup mampu mengikat bahan berkhasiat untuk dicetak menjadi tablet karena selulosa mempunyai sifat penghancur (Lachman and Lieberman, 2004). Selulosa, baik selulosa tongkol jagung maupun Avicel mudah menyerap air kedalam poripori fragmen selulosanya (Niazi and Sarfaraz, 2009).

Tidak ada perbedaan yang bermakna waktu hancur tablet CTM bahan pembantu selulosa tongkol jagung dengan tablet CTM bahan pembantu Aicel, hal ini dapat dilihat pada uji beda rata-rat Duncan Tabel 3.13.

Tabel 4.16 Uji beda rata-rata Duncan terhadap Waktu Hancur Tablet CTM

\begin{tabular}{lllcc}
\hline \multicolumn{1}{c}{ Waktuhancur } & \multirow{2}{*}{ N } & \multicolumn{2}{c}{$\begin{array}{c}\text { Subset for alpha } \\
=0.05\end{array}$} \\
\cline { 3 - 5 } & & 6 & 8.3333 & \\
\hline $\begin{array}{l}\text { Dun } \\
\text { can }^{\mathrm{a}}\end{array}$ & $\begin{array}{l}\text { Tab. CTM Avicel } \\
\text { Tab. CTM Selulosa } \\
\text { tongkol Jagung }\end{array}$ & 6 & 8.5000 & \\
$\begin{array}{l}\text { Tab. Produksi PT. } \\
\text { Pharmaceutical Lab } \\
\text { Sig. }\end{array}$ & 6 & & 13.000 \\
& & 0.776 & 1 \\
\hline
\end{tabular}

4. Kesimpulan Dan Saran

4.1 Kesimpulan

a. Selulosa dari tongkol jagung dapat diisolasi dengan cara maserasi dan hidrolisa mengunakan $\mathrm{HCl}$ yang optimum pada konsentrasi $\mathrm{HCl} 7 \%$ menghasilkan 49,39\% dari berat kering serbuk tongkol jagung.

b. Selulosa yang diisolasi dari tongkol jagung dapat di digunakan sebagai bahan pembantu pembuatan tablet CTM yang dicetak secara langsung. c. Solulosa Tongkol Jagung tidak berbeda nyata $(\alpha=$ 0,05) dengan Avicel dalam hal bahan pembantu pembuatan tablet CTM cara cetak langsung.

\subsection{Saran}

Selulosa tongkol jagung hasil ekstraksi dengan konsentrasi asam klorida yang optimal dapat dimanfaatkan lebih lanjut seperti studi intraksi dengan bahan berkhasiat lain dalam tablet sehingga secara luas dapat digunakan sebagai bahan pengisi, pengikat dan pengembang sediaan tablet cetak langsung.

\section{Daftar Pustaka}

Adel, A.M., Z.H.A. El- Wahab, A.A. Ibrahim, and M.T. Al-Shemy, (2011), Characterization of microcrystalline cellulose prepared from lignocellulosic materials, Part II: Physicochemical properties, Carbohydrate Polymers, Vol. 83.

Ansel C. H., (2008), Pengantar Bentuk Sediaan Farmasi Jakarta UI Press

Badan Pusat Statistik. 2013. Berita Resmi Statistik ,No.45/07/Th.XVI, 1 Juli 2013.

Basiron, Y., B.S. Chan, (2000), Advances in Oil Plam Research, Malaysia Palm Oil Board, Volume II, Ministry Of Primary Industries, Malaysia.

Beltz, H.D and Grosh, W, (2009). Food Chemistry, Second Edition, Springer Verlag Berlin Hedelberg, Jerman.

Ditjen POM, (1995). Farmakope Indonesia Ed IV. Departemen Kesehatan RI, Jakarta.

Fengel, D. dan Wegener, G. (2010). Kayu: Kimia Ultra Struktur Reaksi. Penerjemah Hardjono Sastrohamidjojo, Gadjah Mada University Press, hal 317-446.

Fennema dan Owen. (2010). Food Chemistry. Chemical Publishing Company Inc. New York.

Haafiz, M.K.M, Eichhorn S.J., Hasaan A. and Jawaid M. (2013). Isolation and cheraterization of microcrystalin cellulose from oil palm biomass, Carbohydrat Polymer, Vol 93. No.2. hal 628634.

Halim, F., E.S. Ben, E. Sulastri. (2002). Pembuatan mikrokristal selulosa dari jerami padi dengan variasi waktu hidrolisa. Jurnal Saina dan Teknologi Farmasi. Vol 7. No.2 hal 80-87.

Hsu, T. A., (1996) Pretreatment of Biomass In: Wyman, C.E. (ed) Handbook of Bioethanol, Production and Utilization, Taylor \& Francis, Wasington, DC.

Keshk, S.M.A.S. and M.A. Haija. (2011). A new method for producing microcristallin celluosa from Gluconacetobacter xylinus and kenaf. Carbohydrat Polymers. Vol. 84. Hal. 1301-1305.

Kim, S., J.M. Park, J. W. Seo, and C. H. Kim. (2012) Sequential acid-/alkali-pretreatmen of empty palm fruit bunch fiber. Bioresource. Vol. 109. hal. 229-233. 
Laka, M., S. Chernyavskaya. (2007). Obtaining microcrystalline cellulose from softwood and hardwood pulp, Bioresources. Vol. 2. No. 3. Hal. 583-589.

Lachman, L. and Lieberman, H.A., (.2004) Pharmaceutical Dosage Forms, Marcel Dekker, Inc., USA.

Liu, D., X. Chen, Y. Yueb, M. Chena and Q. Wub. (2011). Structure and rheology of nanocrystalline cellulose. Carbohydrate Polymers. Vo.. 84. Pp. 316-322.

Niazi, and Sarfaraz K., (2009). Handbook of Pharmaceutical Manufacturing Formulations Second Editions : Compressed Solid Products, Informa Healthcare, New York, USA.

Marais, A. F, Song, M dan Villiers, M.M, (2003) Disintegration Propensity of Tablet Evaluated by Means of Disintegrating Force Kinetics Pharmaceutical Development Technology 5 (12) : 163-169

Nishizawa, K. (2002). Degredation celluosa and Hemicelluloses. Biomass Handbook. Gordon \& Breach Science Publisher. New York.

Potter, W., and Norman, N. (2006). Food Science. The AVI Publishing Co, Inc. Westport. Connecticut.
Saigal, N., S. Baboota, A. Ahuja and J. Ali. (2009). Microcrystalline cellulose as a versatile expient in drug research. Journal of Young Pharmacits. Vol. 1. No.1. pp. 6-12.

Sinaga, K. R., (2010). Modefikasi nata de coco dengan tiorena sebagai bahan tambahan sediaan obat fraksi aktif antiradang daun ruku ruku. Tesis. Universitas Sumatera Utara.

Siregar, J. P., Charles dan S. Wikarsa, (2008). Teknologi Farmasi Sediaan Tablet: Dasar-dasar praktis, J. Manurung, N. Aini, dan H.Hadata (Ed). EGJ. Jakarta.

Sjostrom, E. (2005) Kimia Kayu, Dasar-dasar dan Penggunaan. Penerjemah Hardjono Sastrohamidjojo, Gadjah Mada University Press, 1-112.

Suprapto, H.S. dan Rasyid, M. S. (2002). Bertanam Jagung. Penabur Swadaya. Jakarta.

Tranggono, S., Haryadi, Suparmo, A. Murdiati, S. Sudarmadji, K. Rahayu, S. Naruki dan M. Astuti. (1991). Bahan Tambahan Makanan (Food Additive) PAU Pangan dan Gizi. UGM. Yogyakarta. 